\title{
Sodium Selenite
}

National Cancer Institute

\section{Source}

National Cancer Institute. Sodium Selenite. NCI Thesaurus. Code C87346.

An inorg anic form of the trace element selenium with potential antineoplastic activity. Selenium, administered in the form of sodium selenite, is reduced to hydrogen selenide ( $\mathrm{H} 2 \mathrm{Se}$ ) in the presence of glutathione (GSH) and subsequently generates superoxide radicals upon reaction with oxygen. This may inhibit the expression and activity of the transcription factor Sp1; in turn Sp1 down-regulates androgen receptor (AR) expression and blocks AR signaling. Eventually, selenium may induce apoptosis in prostate cancer cells and inhibit tumor cell proliferation. 